\title{
Winter climate change in alpine tundra: plant responses to changes in snow depth and snowmelt timing
}

\author{
Sonja Wipf • Veronika Stoeckli • Peter Bebi
}

Received: 22 February 2008 / Accepted: 19 September 2008 / Published online: 17 February 2009

(C) Springer Science + Business Media B.V. 2009

\begin{abstract}
Snow is an important environmental factor in alpine ecosystems, which influences plant phenology, growth and species composition in various ways. With current climate warming, the snow-to-rain ratio is decreasing, and the timing of snowmelt advancing. In a 2-year field experiment above treeline in the Swiss Alps, we investigated how a substantial decrease in snow depth and an earlier snowmelt affect plant phenology, growth, and reproduction of the four most abundant dwarf-shrub species in an alpine tundra community. By advancing the timing when plants started their growing season and thus lost their winter frost hardiness, earlier snowmelt also changed the number of low-temperature events they experienced while frost sensitive. This seemed to outweigh the positive effects of a longer growing season and hence, aboveground growth was reduced after advanced snowmelt in three of the four species studied. Only Loiseleuria procumbens, a specialist of wind exposed sites with little snow, benefited from an advanced snowmelt. We conclude that changes in the snow cover can have a wide range of species-specific effects on alpine tundra plants. Thus, changes in winter climate and snow cover characteristics should be taken into account when predicting climate change effects on alpine ecosystems.
\end{abstract}

S. Wipf $(\bowtie) \cdot$ V. Stoeckli $\cdot$ P. Bebi

WSL Institute for Snow and Avalanche Research SLF,

Fluelastr. 11, 7260 Davos Dorf, Switzerland

e-mail:wipf@slf.ch

S. Wipf

Institute of Environmental Sciences, University of Zurich,

Winterthurerstr. 190, 8057 Zurich, Switzerland

S. Wipf

The Macaulay Institute, Craijiebuckler, Aberdeen AB15 8QH, UK 


\section{Introduction}

The winter snow cover is one of the fastest changing climate features under current climate change (IPCC 2007). In mountains this is especially evident as an upward shift of the snow line, and hence, a thinner snow cover of shorter duration at low and medium elevations (Laternser and Schneebeli 2003; Lopez-Moreno 2005; Mote et al. 2005). The timing, depth and duration of the snow cover are of special importance to upland ecosystems, as they define the start and duration of the potential growing season (Inouye and Wielgolaski 2003), as well as the temperatures under the snow (Pomeroy and Brun 2001). Although winter precipitation may increase in the future, the proportion falling as rain instead of snow will rise (IPCC 2007), leading to a thinner and less insulating snow cover, which will develop later and melt earlier. Thus, mountain ecosystems may face colder winters, but longer and warmer growing seasons.

In alpine and arctic ecosystems there is a close association between the spatial patterns of snow distribution and the occurrence of vegetation types or plant species (e.g. Evans et al. 1989; Walker et al. 1993; Odland and Munkejord 2008), illustrating the importance of snow depth, snowmelt and season length in structuring communities. Changes in snowmelt timing in alpine ecosystems can immediately affect plant growth (Walker et al. 1993; Galen and Stanton 1995; Wipf et al. 2006; Siffi 2007) and, in the longer term, vegetation composition (Galen and Stanton 1995; Seastedt and Vaccaro 2001; Welch et al. 2005; Wipf et al. 2005). Due to its effects on plant and soil temperatures and soil freezing processes, the snow depth controls biochemical, microbial and plant processes in winter (e.g. Campbell et al. 2005; Sturm et al. 2005), the effects of which can persist well into the growing season (Jones et al. 1998; Weih and Karlsson 2002). Thus, changes in the winter climate are likely to affect ecosystems in seasonally snow covered regions in various ways.

In a field experiment in alpine tundra just above timberline, we factorially reduced the snow depth in winter and advanced snowmelt in spring over 2 years to explore their individual and combined effects on ecosystem processes. The thinner snow cover decreased soil temperatures, and the advanced snowmelt increased the duration of the vegetation period and the temperature sum over summer, but induced lower temperatures just after snowmelt and a higher number of frost days. During the summers following these two winter manipulations, we measured the response in phenology, growth and reproduction of the four most abundant and dominant tundra plant species. We used correlations to explore and interpret the mechanisms leading to changes in plant growth, especially the relationships between growth, phenology, frost occurrence, and temperature.

We hypothesised that changes in snowmelt would have stronger short-term effects on plant performance than changes in snow depth. In particular, we expected an earlier snowmelt to advance the timing of phenological development and thus, to increase plant fitness due to higher temperature sums and a longer snow-free period available for growth and resource allocation. However, we expected the responses to differ between species, which could help to identify the potential winners and losers under long-term climate change. 


\section{Methods}

\subsection{Study site, experimental design and treatments}

The study was conducted at the treeline research site of Stillberg, Davos (Central Alps, Switzerland, $47^{\circ} 28^{\prime} \mathrm{N} 7^{\circ} 30^{\prime} \mathrm{E}$ at 2,200 masl). The local climate (means 1975 to 2004 at 2,090 masl) is characterised by a mean annual precipitation sum of 1,150 mm, $48 \%$ of which falls between June and September. Temperatures average $2.0^{\circ} \mathrm{C}$ over the year, with February as the coldest, and July and August as the warmest months (means $=-4.9^{\circ} \mathrm{C}$ and $9.9^{\circ} \mathrm{C}$, respectively). Snow can fall at any time, but lays continuously from 18 October to 26 May on average, reaching a mean maximum depth of $143 \mathrm{~cm}$. Over these 30 years, the fraction of precipitation falling as snow (i.e. at $\leq 0^{\circ} \mathrm{C}$ ) decreased by $3 \%$ per decade, and the first snow-free day became earlier by 4 days per decade (linear regressions, $F_{1,28}=4.8$ and 5.2, $P=0.04$ and 0.03 ).

The vegetation, growing on a 5-20 cm thick organic layer on Rankers over siliceous gneiss, consists of alpine tundra dominated by deciduous and evergreen dwarf shrubs, with few scattered herbaceous and graminoid species. At sites with visually homogeneous vegetation we established eight blocks, each consisting of four plots of $1 \mathrm{~m}^{2}$ at approx. $4 \mathrm{~m}$ distance. In the winters 2003/2004 and 2004/2005, one combination of the following two treatments was assigned to each plot of a block, resulting in a fully factorial design: (1) reduced snow depth over winter and (2) advanced snowmelt in spring. To reduce the snow cover, and thus, its temperature insulation capacity over winter, we kept its depth at approx. $40 \mathrm{~cm}$ by manually removing snow after each snowfall period. This treatment was stopped towards spring, and snow depths levelled out during the next snowfalls. In spring we advanced snowmelt on half of the plots by carefully reducing the remaining snow from approx. $1 \mathrm{~m}$ to $30 \mathrm{~cm}$, and letting those melt naturally. Due to an unusual warm spell in late spring 2005, the snow cover melted very rapidly, and some plots were snow-free before the snowmelt manipulations even started (they were excluded from analysis). When we reduced the snow cover on the still snow covered early-melting plots on 25 May 2005, we also added 30 to $50 \mathrm{~cm}$ of snow to the remaining control plots to generate significant difference in snowmelt dates between treatments. For simplicity we still call them controls throughout the manuscript.

Over winter, we measured temperatures in $3 \mathrm{~h}$ intervals at the snow/soil interface with temperature loggers (Thermochron iButtons, Maxim Integrated Products, Inc., Sunnyvale, CA, USA) that we installed at soil surface in each plot before snowfall. Thus we were also able to record snow-free periods as days when temperature fluctuations by $>5^{\circ} \mathrm{C}$ or night temperatures of $>0^{\circ} \mathrm{C}$ were measured. Soil temperatures were reduced by the snow removal, especially in the first year (minimum temperatures under the snow: $-2.9^{\circ} \mathrm{C}$ vs. $-4.8^{\circ} \mathrm{C}$ in mid-December $2004,-4.5^{\circ} \mathrm{C}$ vs. $-5.1^{\circ} \mathrm{C}$ in mid-December $2005 ; F_{1,2}=67.9, P=0.01$; unmanipulated snow depth at these times was approx. 40 and $15 \mathrm{~cm}$ ). The snowmelt manipulations advanced snowmelt by 11.3 days in 2004 and by 6.2 days in $2005\left(F_{1,7}=52.6, P<0.001\right.$; Table 1), corresponding to a scenario for 2020 to 2040 based on the rate snowmelt was advancing at the site in previous decades (see above). The snowmelt treatment 
prolonged the potential growing season (between melt-out and first heavy fall frosts with $>-5^{\circ} \mathrm{C}$ temperatures) by $11 \%$ in 2004 and by $6 \%$ in 2005 , and increased the number of frost days (reaching $<0^{\circ} \mathrm{C}$ ) during that period by $45 \%$ in 2004 and $16 \%$ in 2005 (Table 1). Soil moisture during the snow free season (measured at five dates in 2005) was not affected by the snow manipulation treatments, probably due to lateral water flow during snowmelt (data not shown).

\subsection{Plant responses}

We marked four shoots per plot of each of the four most abundant and dominant species, namely the evergreen dwarf shrubs Empetrum nigrum L. ssp. hermaphroditum (Lange ex Hagerup) Böcher and Loiseleuria procumbens (L.) Desv. and the deciduous dwarf shrubs Vaccinium myrtillus L. and $V$. uliginosum L. ssp. gaultherioides Bigelow. Between snowmelt and leave senescence, we visited the plots two to three times weekly to record the number of living shoots, their phenological state, and the number of live flower buds, flowers, and fruits of each marked shoot. We recorded the phenological development as the dates when a shoot entered the following vegetative and reproductive phenophases (=stage of development): (1) shoot snow free, (2) greening up, i.e. reduction of anthocyanins in evergreens, or first leave parts visible in deciduous species, (3) start of shoot growth, (4) onset of fall coloration, (5) burst of first flower buds, (6) first flowers open, and (7) first flowers senescent. Fruit ripening and L. procumbens reproduction did not occur in sufficient numbers to be analysed. From the daily mean temperatures of the nearby weather station we calculated the growing degree days accumulated after greeningup (GDD, i.e. sum of daily mean temperatures above $0^{\circ} \mathrm{C}$ between greening-up and first heavy fall frosts). In 2005, we recorded the shoots with visible frost damages (aborted leaf and flower buds and blackened leave tissue) and calculated the abortion rate of flower buds. Each fall we harvested, dried and weighed the ripe berries of the

Table 1 Effects of the snow depth and snowmelt manipulation treatments in 2004 and 2005 on the environmental variables snowmelt date, number $(n)$ of frost days (i.e. minimum temperatures below freezing), and growing degree days (GDD) above $0^{\circ} \mathrm{C}$ between snowmelt date and the end of the growing season

\begin{tabular}{|c|c|c|c|c|}
\hline \multirow[t]{2}{*}{ Treatments } & \multirow[t]{2}{*}{$N$} & Snowmelt date & \multirow{2}{*}{$\frac{n \text { frost days }}{\text { Mean }(\mathrm{SE})}$} & \multirow{2}{*}{$\frac{\mathrm{GDD}>0^{\circ} \mathrm{C}}{\text { Mean }(\mathrm{SE})}$} \\
\hline & & Mean (SE) & & \\
\hline \multicolumn{5}{|l|}{2004} \\
\hline Overall & 32 & $156.7(1.4)$ & $11.5(0.7)$ & $941(7.3)$ \\
\hline Deep snow & 16 & $157.6(2.0)$ & $11.3(0.9)$ & 933 (11.2) \\
\hline Shallow snow & 16 & $155.8(2.1)$ & 11.7 (1.2) & $949(9.1)$ \\
\hline Early melt & 16 & $151.1(1.8)$ & $13.6(1.1)$ & $970(6.3)$ \\
\hline Control melt & 16 & $162.4(1.0)$ & $9.4(0.6)$ & $913(8.3)$ \\
\hline \multicolumn{5}{|l|}{2005} \\
\hline Overall & 26 & $149.3(0.6)$ & $8.3(0.2)$ & $931(5.3)$ \\
\hline Deep snow & 14 & $149.6(0.9)$ & $8.3(0.4)$ & $929(7.6)$ \\
\hline Shallow snow & 12 & $148.9(0.9)$ & $8.3(0.3)$ & $933(7.6)$ \\
\hline Early melt & 14 & $146.4(0.2)$ & $8.9(0.3)$ & $949(5.1)$ \\
\hline Control melt & 12 & $152.6(0.4)$ & $7.7(0.3)$ & $910(5.4)$ \\
\hline
\end{tabular}

Snowmelt date given as day of year

$N$ number of plots per treatment 
marked shoots and measured the leaf lengths of approx. 20 leaves per species and plot. As a measure of belowground productivity, we quantified root production in 4 blocks (=16 plots) by burying root ingrowth cores, i.e. root-free organic soil cores (depth $10 \mathrm{~cm}$, diameter $3 \mathrm{~cm}$ ) in a nylon mesh (mesh size $1 \mathrm{~mm}$ ) in October 2003, and quantifying root biomass grown into the cores by 30 August 2004. In October 2005 we harvested all marked shoots and measured their above ground growth as the annual growth increments of the last 2 years.

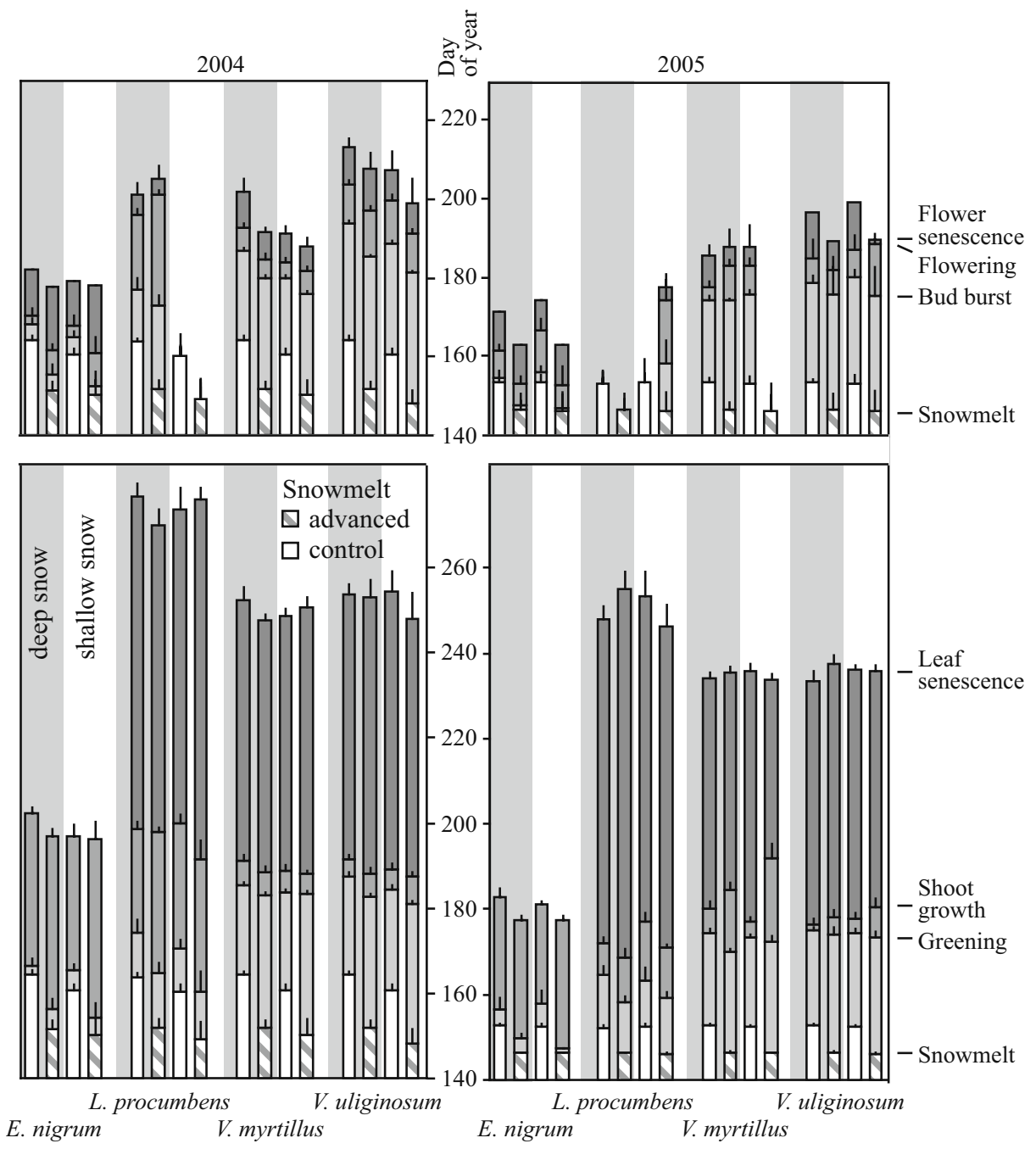

Fig. 1 Phenology of the vegetative (above) and reproductive (below) development of four alpine dwarf shrub species subject to manipulations in snow depth and snowmelt timing in 2004 and 2005. The phenological stages recorded after snowmelt were: leaf greening, start of shoot growth, start of leaf senescence/fall coloration, bud break of flower buds, start of flowering, and start of flower senescence. Error bars $= \pm 1$ SE. For full species names see text 


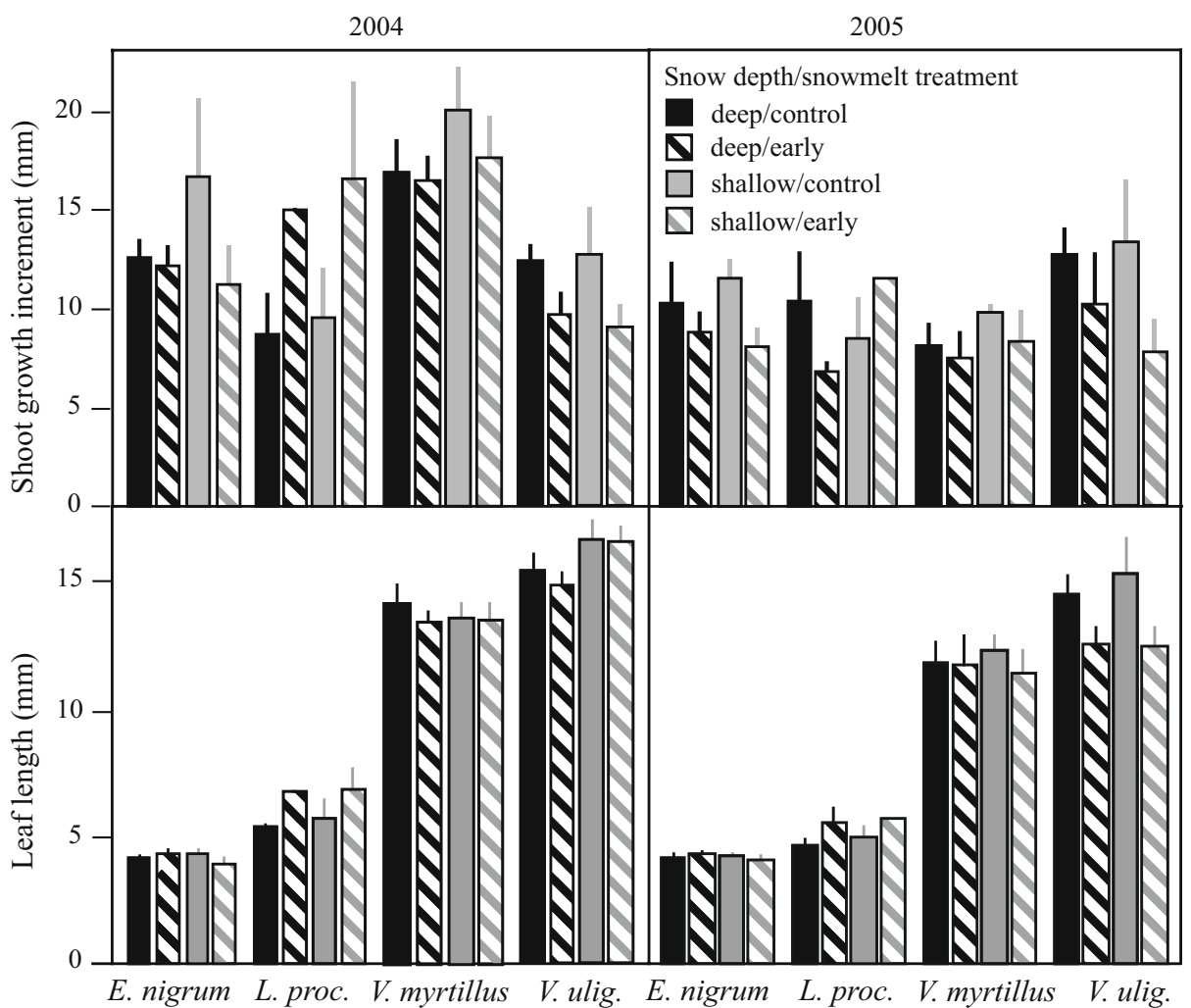

Fig. 2 The growth response of shoots (above) and leaves (below) of four alpine dwarf shrubs species to manipulations in snow depth and snowmelt timing in 2004 and 2005 . Error bars $= \pm 1 \mathrm{SE}$

\subsection{Statistical analyses}

All data per species and plot were pooled and analysed for the effects of the snow manipulation treatments with ANOVAs with Type I Sums of Squares. We analysed whether the response variables differed between years, snowmelt and snow depth treatments, and tested for interactions between these factors. Due to the blockwise structure of the experiment, we defined year, snowmelt and snow depth treatments as fixed and block as random factors. Residuals were visually checked and variables transformed where necessary to meet the assumptions of ANOVA (Appendix). Analyses were conducted in SPSS 11.0 (SPSS Inc 2001).

Fig. 3 The relationship between the number of frost days experienced by four dwarf shrub species after starting their life cycle in spring, a the occurrence of frost damaged flower buds and leaves and b shoot growth, and c the relationship between growing degree days and shoot growth. Significant correlations are indicated in solid lines and with $R^{2}$ values, non-significant ones with dashed lines 
a)

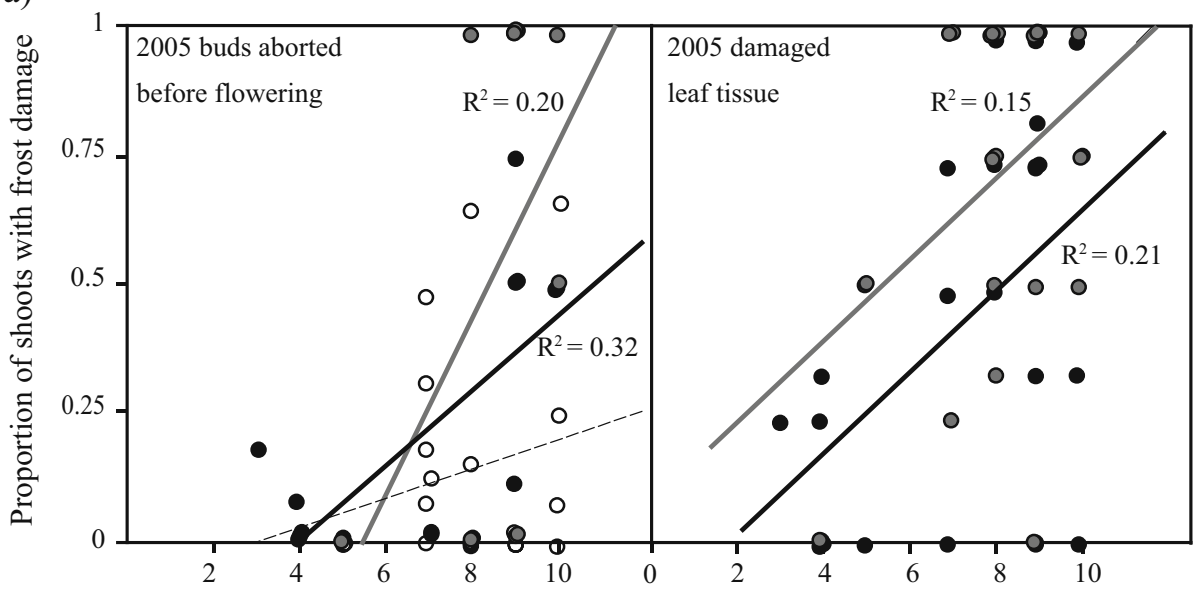

Frost days after greening-up (N)

b)

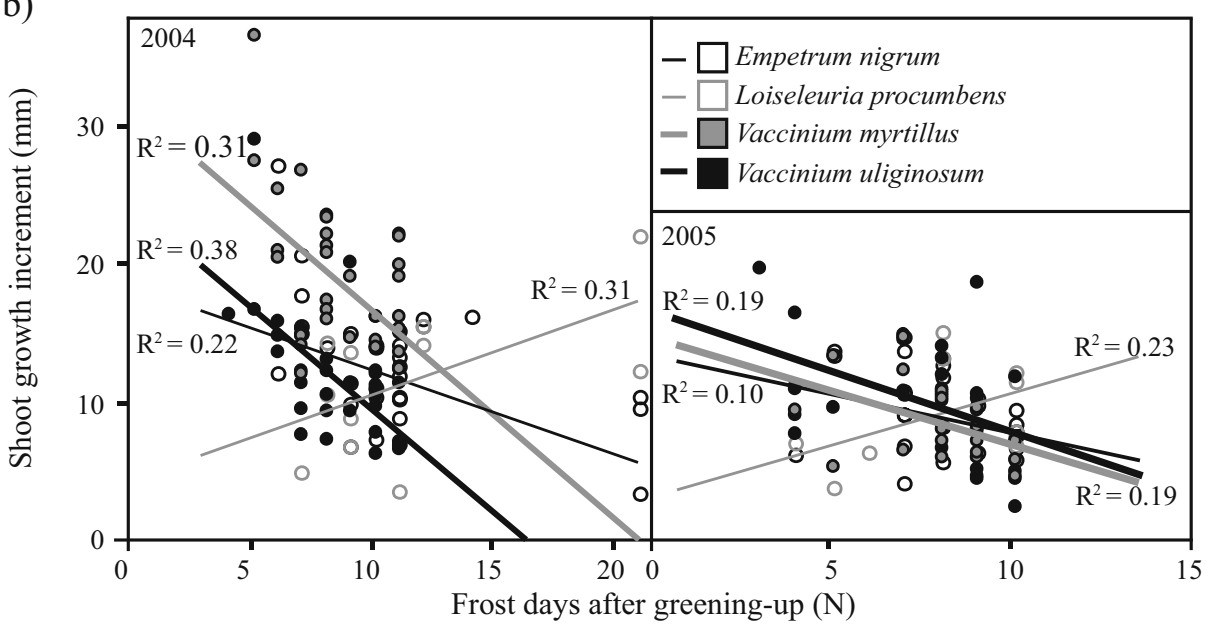

c)

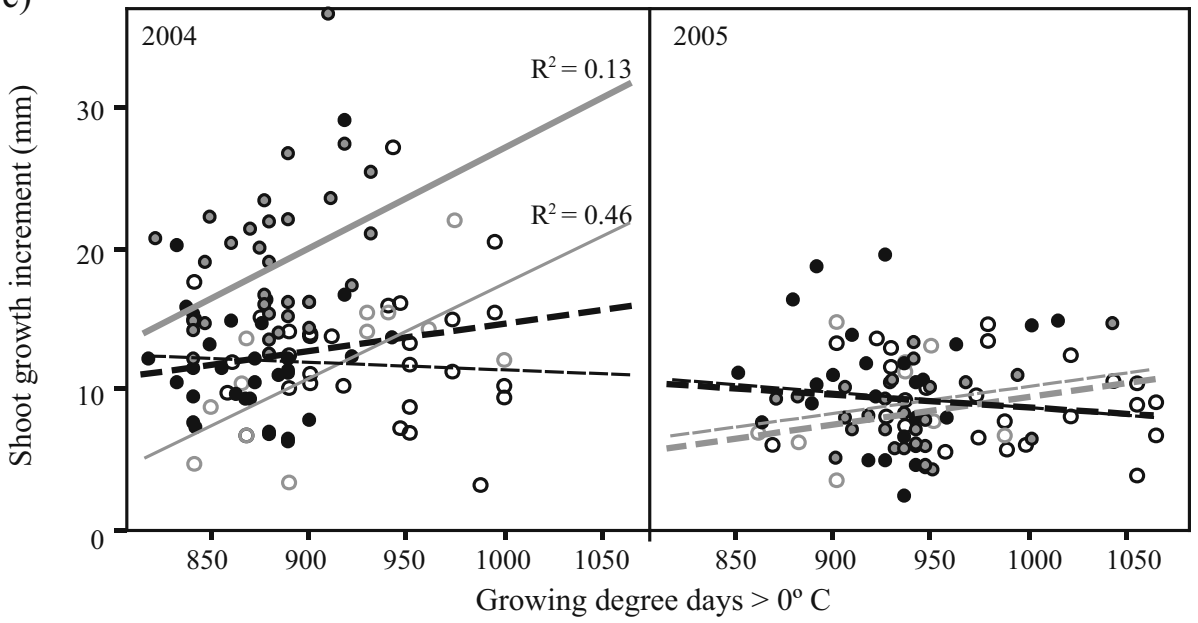




\section{Results}

The phenological development of all species was clearly influenced by changes in the snow cover (Fig. 1; Table 2). The greening-up, which is the first sign of seasonal plant activity, was advanced by earlier snowmelt in all four species, and also advanced by reduced snow in both Vaccinium species. An earlier snowmelt also advanced the start of shoot growth of E. nigrum (marginally significant), L. procumbens, and $V$. uliginosum (in 2004 only), but delayed that of V. myrtillus, especially in 2005 and in plots with reduced snow cover. In 2004, leave senescence of both Vaccinium species tended to start earlier after advanced snowmelt. Early snowmelt advanced all reproductive phenophases of all three species it was analysed for, but not all effects were statistically significant (Fig. 1; Table 2). A reduced winter snow cover further advanced flowering and flower senescence, but only significantly so in $V$. uliginosum.

Although an earlier snowmelt advanced the start of all species' life cycle, and thus, increased the growing degree days they accumulated, the annual growth increments and leaf lengths of E. nigrum, $V$. myrtillus and $V$. uliginosum, were generally decreased after early snowmelt (but not in all cases significantly; Fig. 2; Appendix). L. procumbens differed from this prevalent pattern: its shoots and leaves grew larger after earlier snowmelt, especially in 2004 (Fig. 2). The reduced winter snow depth did not significantly alter aboveground growth, but decreased the total root mass in root ingrowth cores by $55 \%$ (from 34.7 to $15.7 \mathrm{mg}, F_{1,9}=5.4, P=0.05$ ). A positive effect of temperature (i.e. increased growing degree days) on shoot growth was only found in L. procumbens and V. myrtillus in 2004, but not in the other species and years (Fig. 3). The proportion of Vaccinium sp. shoots with visible frost damage in 2005 was more than doubled by advanced snowmelt (from $46.5 \%$ to $93.3 \%$ in $V$. myrtillus, $F_{1,6}=19.3, P=0.005$, from $23.6 \%$ to $64.3 \%$ in $V$. uliginosum, $F_{1,6}=6.0, P=0.05$ ) and was correlated with the number of frosts that shoots experienced after greeningup (Fig. 3). The more frost days E. nigrum and Vaccinium shoots experienced after greening-up, the less they grew in that year, however, the correlation between frost occurrence and L. procumbens growth was a positive one (Fig. 3).

An advanced snowmelt and a higher number of frost days after greening-up resulted in a higher proportion of buds of both Vaccinium species killed before flowering in 2005 (Fig. 3). The fecundity (=proportion of shoots with ripe fruits) in these two species did not differ between treatments. The fecundity of L. procumbens was decreased with reduced snow cover over winter (from $2.1 \%$ to $0 \% ; F_{1,6}=5.7$, $P=0.05$ ). Shallow snow cover reduced fecundity in E. nigrum, but only in 2005 (from $23.1 \%$ to $6.9 \%$; snow depth $\times$ year: $F_{1,6}=13.3, P=0.01$ ). E. nigrum berries, however, were heavier in plots with earlier snowmelt, especially in 2005 (24.8 vs. $20.6 \mathrm{mg}$, snowmelt treatment: $F_{1,7}=4.3, P=0.08$; snowmelt treatment $\times$ year: $\left.F_{1,5}=9.0, P=0.03\right)$.

\section{Discussion}

Our field experiment is to our knowledge the first to manipulate factorially the presence and depth of the alpine snow cover and to study simultaneously the role of two of the key variables that control winter and spring conditions experienced by alpine plants. By disentangling their effects on the phenology and fitness of four 


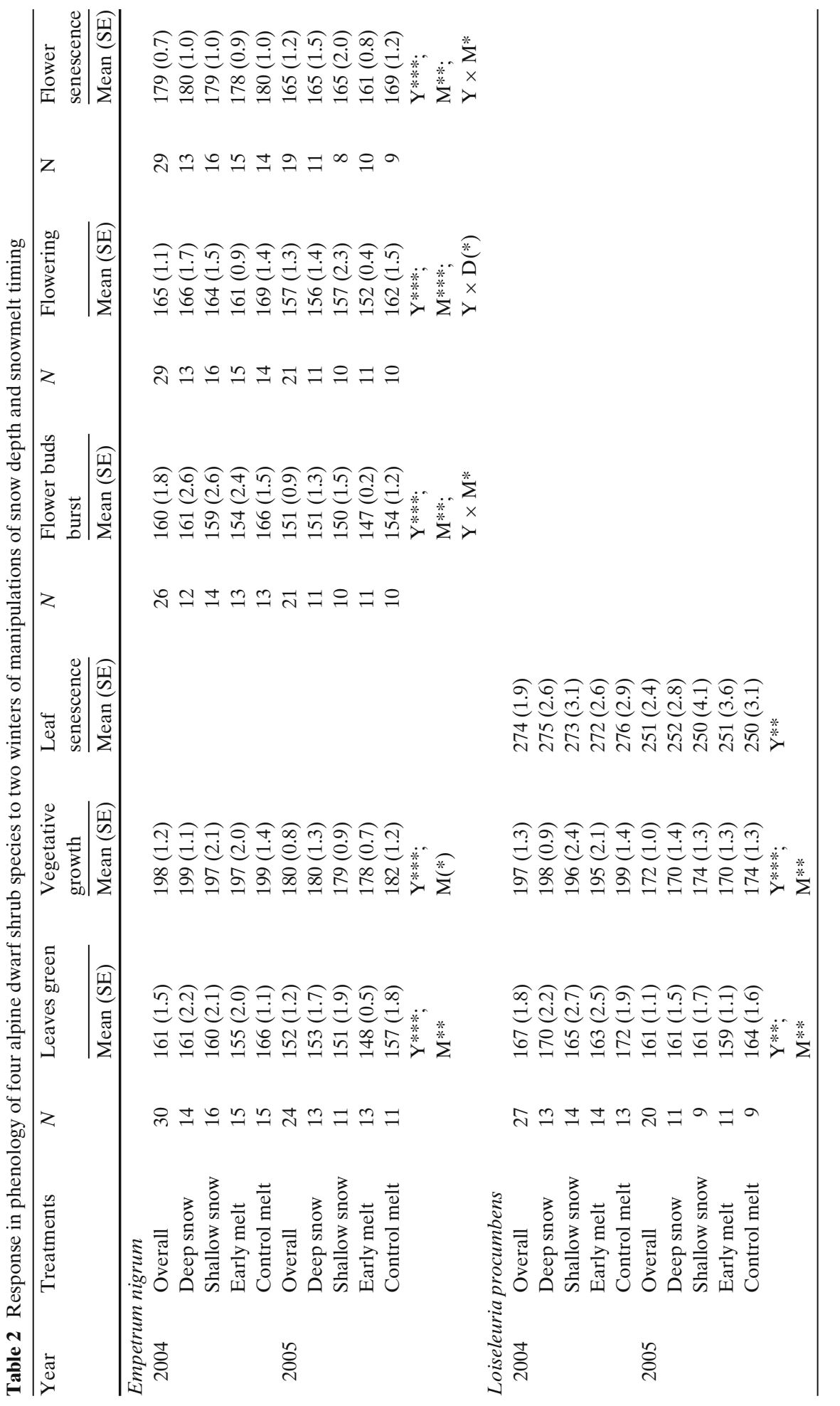




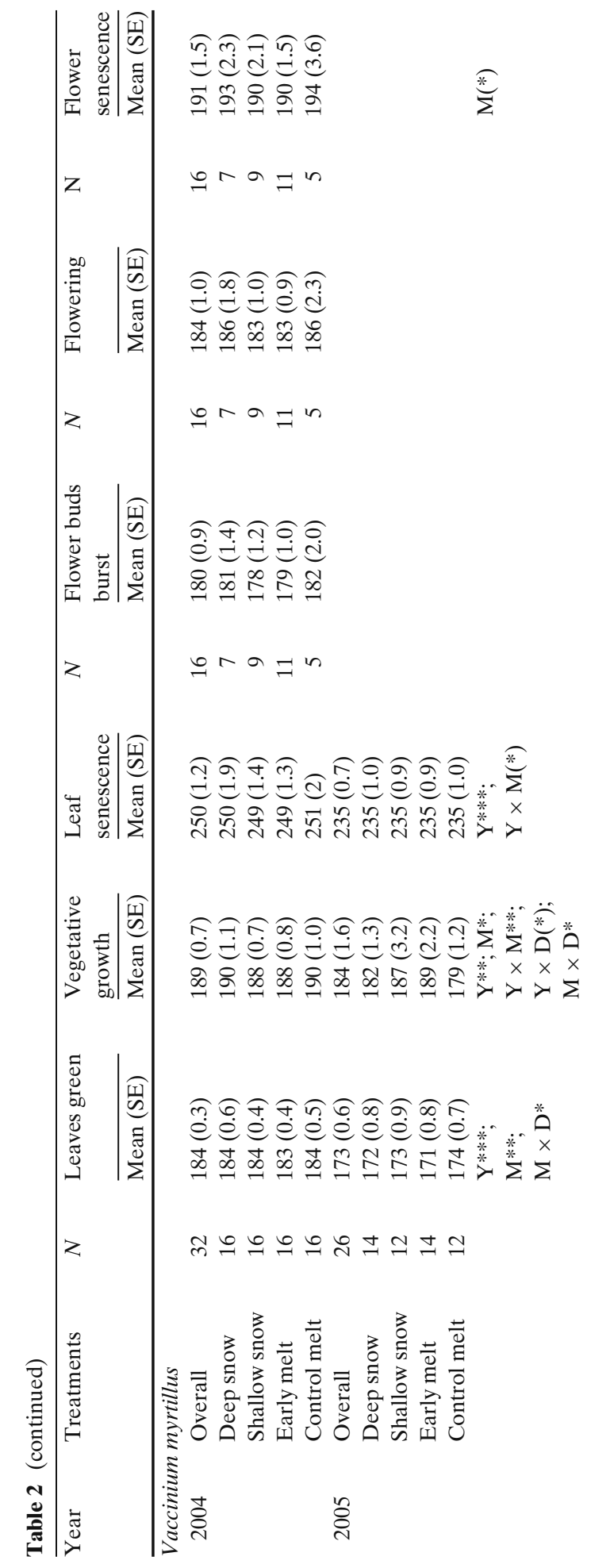




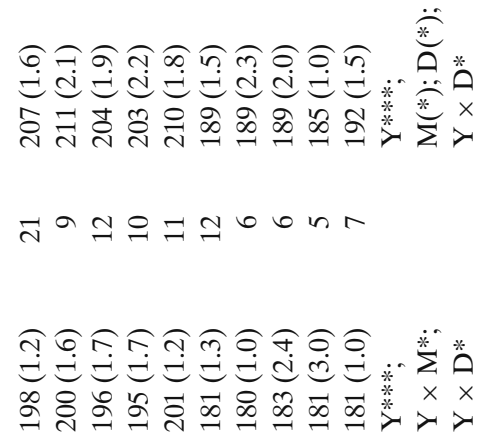

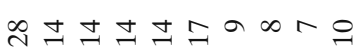

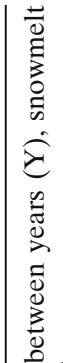

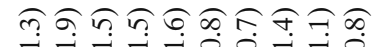

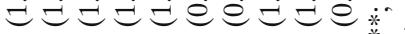

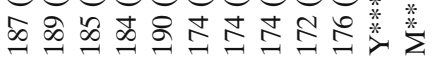

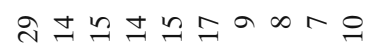

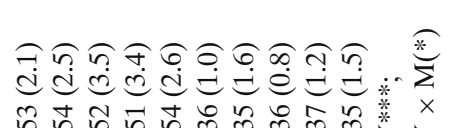

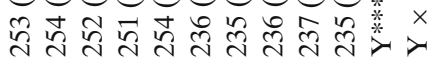

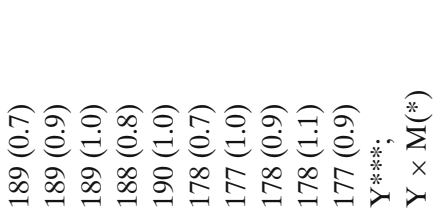

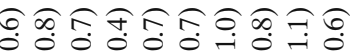

e e e e e

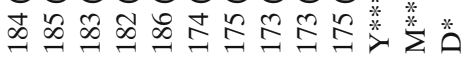

m느는ㅁำำ

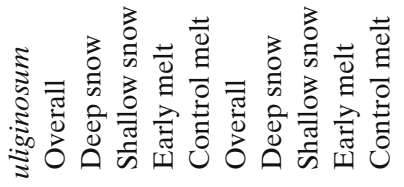

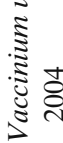

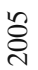


widespread tundra species, our experiment contributes to the understanding of these species' sensitivities to different abiotic factors and of the consequences of winter climate change on alpine plant communities.

Our results confirm that both the depth and the timing of disappearance of the snow cover have important implications for plant phenology, growth and reproduction, but that snowmelt timing has stronger effects than snow depth. The phenological development was generally advanced after earlier snowmelt, which could potentially foster plant fitness by extending the period available for growth and resource allocation (Galen and Stanton 1993; Stinson 2004). Three out of four plant species, however, were not able to turn the longer growing season into increased growth and reproduction, which is in line with other snow removal studies in upland ecosystems (Saavedra 2002; Wipf et al. 2006; Siffi 2007). The one species that responded positively to advanced snowmelt was Loiseleuria procumbens, which tended to produce longer shoots and leaves. L. procumbens is a specialist of windswept ridges with little or lacking winter snow cover (Grabherr 1980) and is noted for its extreme winter frost hardiness (Koerner 1999). Although it is much more frost sensitive in summer, at ca. $-7^{\circ} \mathrm{C}$ it is still more frost hardy than the other species studied here (Ulmer 1937; Taschler and Neuner 2004), and thanks to its prostrate life form, it may profit from some protection by other species (Jordan and Smith 1995). In the following year 2006 without major frost events, however, V. myrtillus growth increased after early snowmelt (subsample of this experiment, C. Schwoerer, unpublished data). These findings, together with the negative relationship between frost occurrence and growth, suggest that frosts might play an important role for the survival, growth and reproduction of alpine plant species in a changing climate (see Inouye 2000 for a review on this topic). The positive correlation of frost occurrence and $L$. procumbens shoot growth even suggests that this prostrate plant might benefit from the frost damage to the other, larger growing species.

The interaction between snowmelt timing and phenology can control the amount of frost damage in two ways. First, the start of the life cycle and loss of frost hardiness occurs earlier after advanced snowmelt and thus, plants experience a higher number of frost events while in a relatively frost sensitive stage. Second, by starting the formation of apical meristems and buds earlier, plants also have "more to lose", should low temperature extremes occur. Although alpine and arctic plants are generally able to replace frost aborted shoots and leaves within the same growing season (e.g. $V$. myrtillus in our experiment), frost damage severely reduces plant growth and fecundity in the short term (Molgaard and Christensen 1997; Price and Waser 1998; Inouye et al. 2002), and may even become lethal if occurring several years in a row, as plant resources may be depleted (Molau 1997). A strategy to reduce frost damages in a fluctuating or changing climate is photoperiodism, i.e. a plant's ability to time its development according to a certain day length. This allows many alpine species to remain frost hardy until later in summer, when growing conditions are more favourable (Koerner 1999; Keller and Korner 2003). In the absence of frosts, on the other hand, this mechanism inhibits plants from benefiting from warmer temperatures and longer growing periods.

By removing snow without increasing spring temperatures (unlike e.g. Harte and Shaw 1995 or Oberbauer et al. 1998, who applied additional warming treatments), our experiment caused the seemingly paradox climate scenario of a colder spring in a warmer world. In snow-rich regions, the amount of snow does not only control the 
plant and soil temperatures in winter, but also the temperatures that the plants first experience in spring. Due to the interaction of a shallower snow cover and warmer spring temperatures, snowmelt can shift to an earlier, naturally colder period of the year. Accordingly, long-term data from the Colorado Rocky Mountains, a region with a snow and temperature regime comparable to ours, show that while the amount of snow decreased and snowmelt timing advanced, the amount of frost damage on alpine plants strongly increased, regardless of an overall warming trend (Inouye et al. 2002; Inouye 2008). Hence, whether frost events will increase or decrease depends on the balance between warmer spring temperatures (which generally decrease the occurrence of frost events) and earlier snowmelt (which increases the risk that plants experience frosts while not covered in snow).

The decreased snow depth, which induced colder soil temperatures throughout most of the winter, had little direct effect on plant phenology and aboveground growth. Our snow reduction treatment did not expose plants during winter, thus, rather than aboveground plant parts, we would expect snow depth manipulations to affect belowground processes. In fact the snow reduction treatment did decrease root production in the following summer in our study. This contrasts with another snow manipulation experiment, where decreased snow cover stimulated root turnover (Tierney et al. 2001), probably because soil freezing and the associated soil heaving damaged the fine roots and stimulated their replacement growth in the following spring. Whether the different results are caused by the different methods used in these studies or represent a biological pattern remains unclear. Our experiment (Bauer, unpublished data) as well as other studies (Fitzhugh et al. 2001; Groffman et al. 2001) found that reduced snow depth and winter temperatures increased mobile soil nitrogen, which can be used by microbes, but also by plants in spring (Bilbrough et al. 2000). Hence, if reduced snow depth and soil freezing can affect aboveground plant growth at all, the extent may depend on the balance between the negative (root damage) and positive effects (increased nutrient availability).

In conclusion, our study shows that plant responses to winter climate change and modifications of the snow cover strongly differ among species. The fact that plants respond differently to changes in the same abiotic variable suggests that the interaction between plant species (Wipf et al. 2006), but also between plants and their pollinators, pests or pathogens, may be disrupted (Roy et al. 2004). Such mechanisms have a great potential to mediate or amplify effects of climate change on community composition. The important role of frost events on the outcome of our experiment underlines the importance of incorporating extreme nonlinear climate factors into analyses and predictions of climate change effects. The ongoing snow manipulations of our experiment will show whether the initial changes in species fitness and reproduction found after the first 2 years will proceed over the longer term and will eventually result in significant changes in community composition and structure.

Acknowledgements We thank Andrea Schleicher and Pascal Wiesli for the help in the field, Christian Rixen, Bernhard Schmid, and two anonymous reviewers for the helpful suggestions, and numerous friends and volunteers who helped moving approx. $50 \mathrm{t}$ of snow. Funding was provided by the WSL Institute for Snow and Avalanche Research SLF, part of the Swiss Federal Institute for Forest, Snow and Landscape Research WSL. 


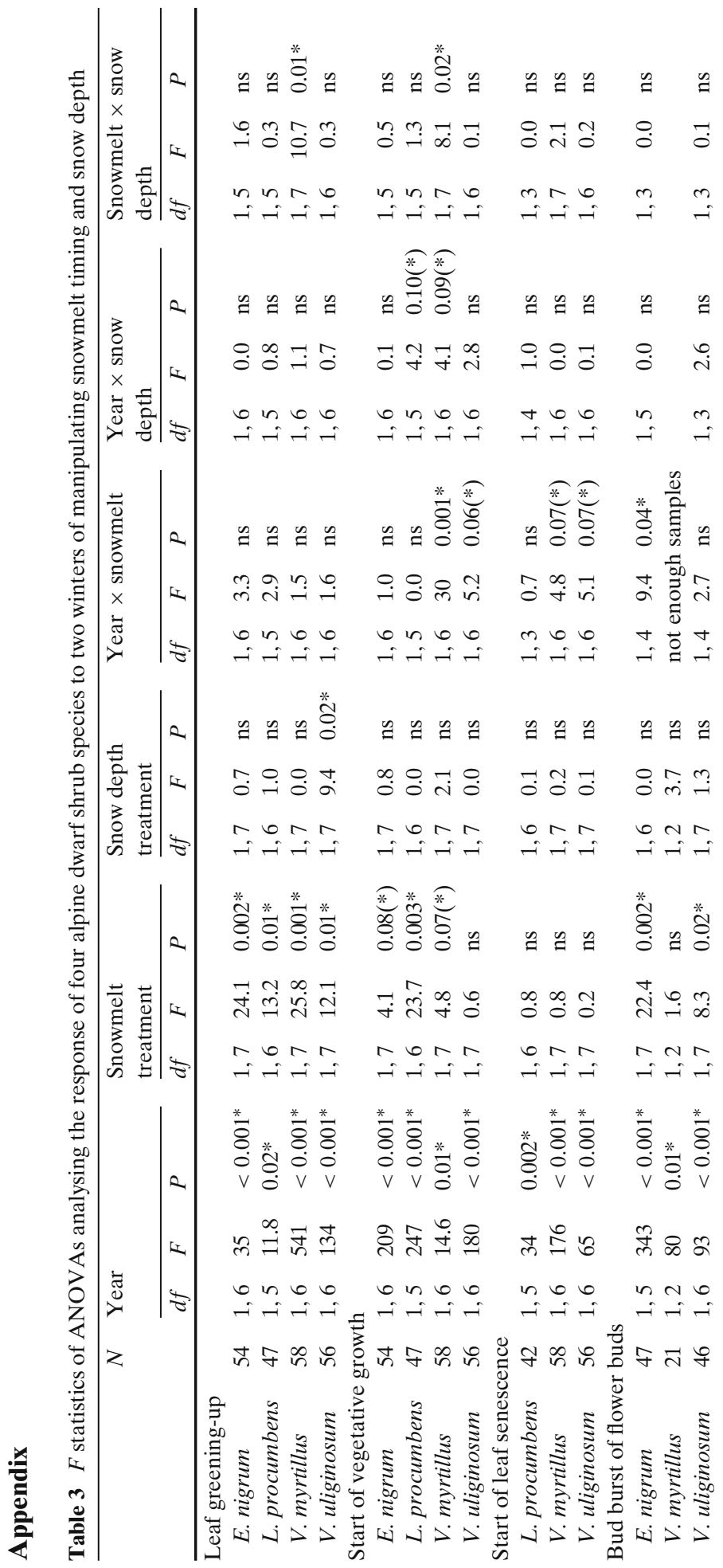




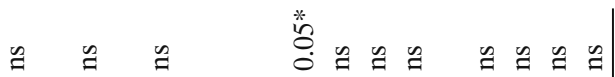

न1

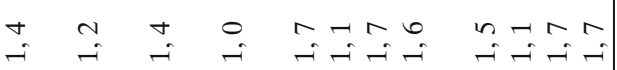

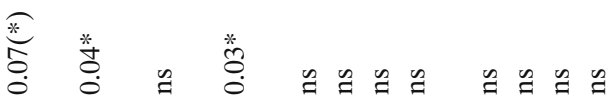

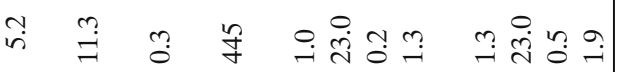

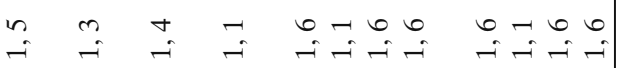

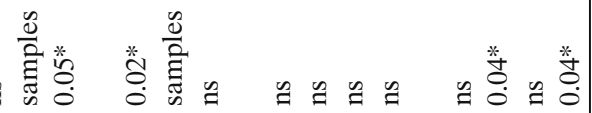

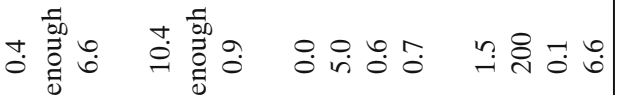

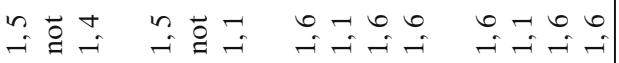

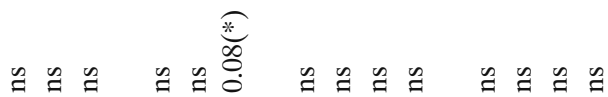

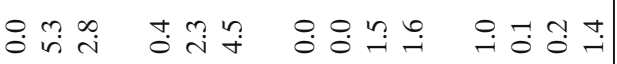
ma no nan

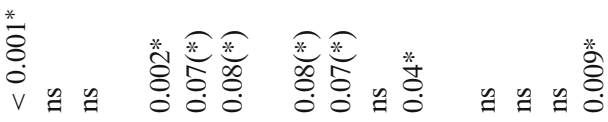

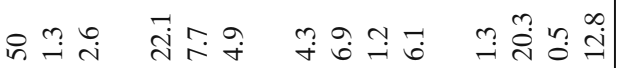
nm n n n n n n n

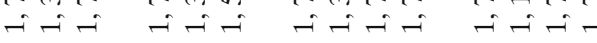

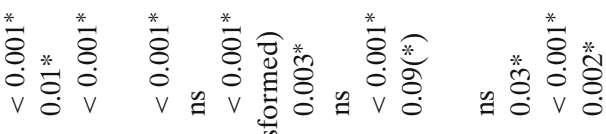
กิ - $=$ भे

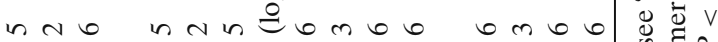

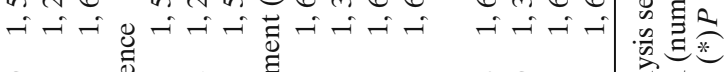

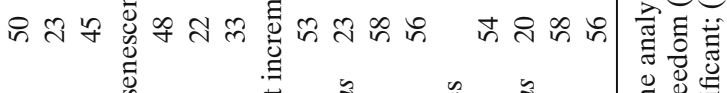

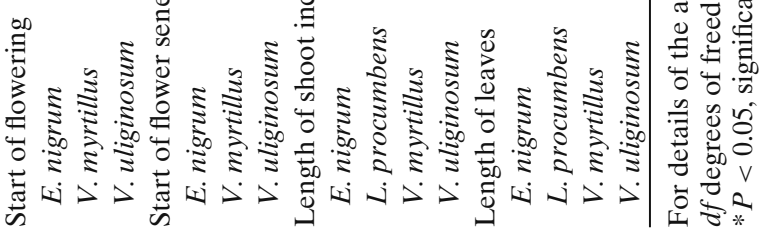




\section{References}

Bilbrough CJ, Welker JM, Bowman WD (2000) Early spring nitrogen uptake by snow-covered plants: a comparison of arctic and alpine plant function under the snowpack. Arct Antarct Alp Res 32:404-411

Campbell JL, Mitchell MJ, Groffman PM et al (2005) Winter in northeastern North America: an often overlooked but critical period for ecological processes. Front Ecol Environ 3:314-322

Evans BM, Walker DA, Benson CS et al (1989) Spatial interrelationships between terrain, snow distribution and vegetation patterns at an arctic foothills site in Alaska. Holarct Ecol 12:270-278

Fitzhugh RD, Driscoll CT, Groffman PM et al (2001) Effects of soil freezing disturbance on soil solution nitrogen, phosphorus, and carbon chemistry in a northern hardwood ecosystem. Biogeochemistry 56:215-238

Galen C, Stanton ML (1993) Short-term responses of alpine buttercups to experimental manipulations of growing-season length. Ecology 74:1052-1058

Galen C, Stanton ML (1995) Responses of snowbed plant-species to changes in growing-season length. Ecology 76:1546-1557

Grabherr G (1980) Variability and ecology of the alpine dwarf shrub community LoiseleurioCetrarietum. Plant Ecol 41:111-120

Groffman PM, Driscoll CT, Fahey TJ et al (2001) Effects of mild winter freezing on soil nitrogen and carbon dynamics in a northern hardwood forest. Biogeochemistry 56:191-213

Harte J, Shaw R (1995) Shifting dominance within a montane vegetation community—results of a climate-warming experiment. Science 267:876-880

Inouye DW (2000) The ecological and evolutionary significance of frost in the context of climate change. Ecol Lett 3:457-463

Inouye DW (2008) Effects of climate change on phenology, frost damage, and floral abundance of montane wildflowers. Ecology 89:353-362

Inouye DW, Wielgolaski FE (2003) High altitude climates. In: Schwartz MD (ed) Phenology: an integrative environmental science. Kluwer, Dordrecht, The Netherlands, pp 195-214

Inouye DW, Morales MA, Dodge GJ (2002) Variation in timing and abundance of flowering by Delphinium barbeyi Huth (Ranunculaceae): the roles of snowpack, frost, and La Niña, in the context of climate change. Oecologia 130:543-550

IPCC (ed) (2007) Climate change 2007: the physical science basis. Contribution of working group I to the fourth assessment report of the intergovernmental panel on climate change. Cambridge University Press, Cambridge, New York

Jones MH, Fahnestock JT, Walker DA et al (1998) Carbon dioxide fluxes in moist and dry arctic tundra during the snow-free season: responses to increases in summer temperature and winter snow accumulation. Arct Alp Res 30:373-380

Jordan DN, Smith WK (1995) Microclimate factors influencing the frequency and duration of growth season frost for sub-alpine plants. Agric For Meteorol 77:17-30

Keller F, Korner C (2003) The role of photoperiodism in alpine plant development. Arct Antarct Alp Res 35:361-368

Koerner C (1999) Alpine plant life. Springer, Berlin

Laternser M, Schneebeli M (2003) Long-term snow climate trends of the Swiss Alps (1931-99). J Climatol 23:733-750

Lopez-Moreno JI (2005) Recent variations of snowpack depth in the central Spanish Pyrenees. Arct Antarct Alp Res 37:253-260

Molau U (1997) Phenology and reproductive success in arctic plants: susceptibility to climate change. In: Oechel WC, Callaghan T, Gilmanov TG et al (eds) Global change and arctic terrestrial ecosystems. Springer, New York, pp 153-170

Molgaard P, Christensen K (1997) Response to experimental warming in a population of Papaver radicatum in Greenland. Global Change Biol 3:116-124

Mote PW, Hamlet AF, Clark MP et al (2005) Declining mountain snowpack in western North America. Bull Am Meteorol Soc 86:39-49

Oberbauer SF, Starr G, Pop EW (1998) Effects of extended growing season and soil warming on carbon dioxide and methane exchange of tussock tundra in Alaska. J Geophys Res 103:2907529082

Odland A, Munkejord HK (2008) Plants as indicators of snow layer duration in southern Norwegian mountains. Ecological Indicators 8(1):57-68 
Pomeroy JW, Brun E (2001) Physical properties of snow. In: Jones HG, Pomeroy JW, Walker DA et al (eds) Snow ecology. Cambridge University Press, Cambridge, pp 45-126

Price MV, Waser NM (1998) Effects of experimental warming on plant reproductive phenology in a subalpine meadow. Ecology 79:1261-1271

Roy BA, Gusewell S, Harte J (2004) Response of plant pathogens and herbivores to a warming experiment. Ecology 85:2570-2581

Saavedra F (2002) Testing climate change predictions with the subalpine species Delphinium nuttallianum. In: Schneider SH, Root TL (eds) Wildlife responses to climate change. Island Press, Washington, pp 201-249

Seastedt TR, Vaccaro L (2001) Plant species richness, productivity, and nitrogen and phosphorus limitations across a snowpack gradient in alpine tundra, Colorado, USA. Arct Antarct Alp Res 33:100-106

Siffi C (2007) Effetto della variazione della copertura nevosa in una brughiera soprasilvatica dell'Appennino Settentrionale. PhD Thesis, Università degli Studi di Ferrara

SPSS Inc (2001) SPSS 11.0.0. Chicago

Stinson KA (2004) Natural selection favors rapid reproductive phenology in Potentilla pulcherrima (Rosaceae) at opposite ends of a subalpine snowmelt gradient. Am J Bot 91:531-539

Sturm M, Schimel J, Michaelson G et al (2005) Winter biological processes could help convert arctic tundra to shrubland. BioScience 55:17-26

Taschler D, Neuner G (2004) Summer frost resistance and freezing patterns measured in situ in leaves of major alpine plant growth forms in relation to their upper distribution boundary. Plant Cell Environ 27:737-746

Tierney GL, Fahey TJ, Groffman PM et al (2001) Soil freezing alters fine root dynamics in a northern hardwood forest. Biogeochemistry 56:175-190

Ulmer W (1937) Ueber den Jahresgang der Frosthaerte einiger immergruener Arten der alpinen Stufe, sowie Zirbe und Fichte. Jahrbuecher fuer wissenschaftliche Botanik 84:553-592

Walker DA, Halfpenny JC, Walker MD et al (1993) Long-term studies of snow-vegetation interactions. BioScience 43:287-301

Weih M, Karlsson PS (2002) Low winter soil temperature affects summertime nutrient uptake capacity and growth rate of mountain birch seedlings in the Subarctic, Swedish Lapland. Arct Antarct Alp Res 34:434-439

Welch D, Scott D, Thompson DBA (2005) Changes in the composition of Carex bigelowiiRacomitrium lanuginosum moss heath on Glas Maol, Scotland, in response to sheep grazing and snow fencing. Biol Conserv 122:621-631

Wipf S, Rixen C, Fischer M et al (2005) Effects of ski piste preparation on alpine vegetation. J Appl Ecol 42:306-316

Wipf S, Rixen C, Mulder CPH (2006) Advanced snowmelt causes shift towards positive neighbour interactions in a subarctic tundra community. Glob Chang Biol 12:1496-1506 